\title{
KARAKTER KIMIAWI TEMPE JAGUNG PULUT DENGAN WAKTU FERMENTASI BERBEDA
}

(Chemical characters of waxy maize tempeh with different fermentation times)

\author{
Arif Murtaqi Akhmad Mutsyahidan', Salma S. Husain ${ }^{2}$, dan Rosdiani Azis ${ }^{3}$ \\ ${ }^{1,2,3}$ Politeknik Gorontalo, Program Studi Teknologi Hasil Pertanian \\ Jl. Muchlis Rahim, Desa Panggulo Barat, Kecamatan Botupingge, \\ Kabupaten Bone Bolango, Provinsi Gorontalo, Kode Pos 96583 \\ Email: arifmams@poligon.ac.id
}

\begin{abstract}
ABSTRAK
Tujuan penelitian ini adalah mengetahui karakter kimiawi tempe jagung pulut yang dihasilkan dengan proses waktu fermentasi yang berbeda-beda. Uji yang dilakukan adalah kadar air, kadar abu, dan $\mathrm{pH}$. Penelitian ini menggunakan beberapa perlakuan waktu fermentasi yaitu $\mathrm{A} 1=42 \mathrm{jam}, \mathrm{A} 2=45 \mathrm{jam}$, dan $\mathrm{A} 3=48 \mathrm{jam}$. Hasil penelitian menunjukkan kadar air tertinggi terdapat pada perlakuan fermentasi 42 jam dengan nilai $65,57 \%$, nilai kadar abu tertinggi terdapat pada perlakuan fermentasi 42 jam dengan nilai $0,48 \%$, nilai derajat keasaman $(\mathrm{pH})$ terendah terdapat pada perlakuan fermentasi 48 jam sebesar 5,2.
\end{abstract}

Kata Kunci: Tempe; jagung pulut; waktu fermentasi.

\section{ABSTRACT}

The purpose of this study was to determine the character of waxy maize tempeh produced with different fermentation time processes. The tests carried out were water content, ash content, and $\mathrm{pH}$. This study used several fermentation time treatments, namely A1 $=42$ hours, A2 $=45$ hours, and A3 $=48$ hours. The results showed that the highest water content was found in the 42 -hour fermentation treatment with a value of $65.57 \%$, the highest ash content value was in the 42-hour fermentation treatment with a value of $0.48 \%$, the lowest value of acidity $(\mathrm{pH})$ was in the 48 -hour fermentation treatment of 5.2.

Keywords: Tempeh; waxy maize; fermentation time

\section{PENDAHULUAN}

Tempe merupakan makanan yang banyak digemari masyarakat. Pembuatan tempe umumnya menggunakan bahan baku kedelai. Kedelai diolah menjadi tempe melalui fermentasi dengan Rhizopus oligosporus yang memecah nutrisi komplek kedelai menjadi senyawa yang lebih sederhana secara enzimatis (Hanifah, 2015).
Produksi kacang kedelai di Indonesia belum memenuhi kebutuhan pembuatan tempe. Bahkan kacang kedelai masih sering diimpor dari luar negeri. Penggunaan jagung sebagai pengganti kedelai dalam pembuatan tempe menjadi salah satu alternatif untuk mengatasi hal tersebut (Lestari dan Mayasari. 2016).

Berdasarkan data BPS (2016), produksi jagung di Gorontalo tahun 2015 cukup melimpah tercatat 643.513 ton. 
Varietas jagung yang dibudidayakan di Gorontalo salah satunya jagung pulut. Untuk meningkatkan nilai tambah dan pemanfaatan dari jagung pulut, maka dapat dilakukan pengolahan jagung menjadi produk-produk turunan misalnya diolah menjadi tempe.

Keberhasilan dalam proses pembuatan tempe sangat tergantung pada banyak aspek, salah satunya pada proses fermentasi. Penelitian ini bertujuan untuk membandingkan karakter kimiawi tempe yang dibuat dengan waktu fermentasi yang berbeda-beda.

\section{METODE PENELITIAN}

Prosedur penelitian mengacu pada penelitian Lestari dan Mayasari (2016), dan penelitian Eliyana (2017) yang kemudian dimodifikasi oleh peneliti.

Adapun modifikasi tempe jagung pulut yang dilakukan yaitu :

a. Perlakuan $\mathrm{A} 1=$ jagung pulut 100 gram : ragi 0,15 gram : waktu fermentasi 42 jam

b. Perlakuan A2 = jagung pulut 100 gram : ragi 0,15 gram : waktu fermentasi 45 jam

c. Perlakuan A3 = jagung pulut 100 gram : ragi 0,15 gram : waktu fermentasi 48 jam
Prosedur pembuatan tempe jagung pulut (Gambar 1) mengacu pada penelitian Eliyana (2017) :
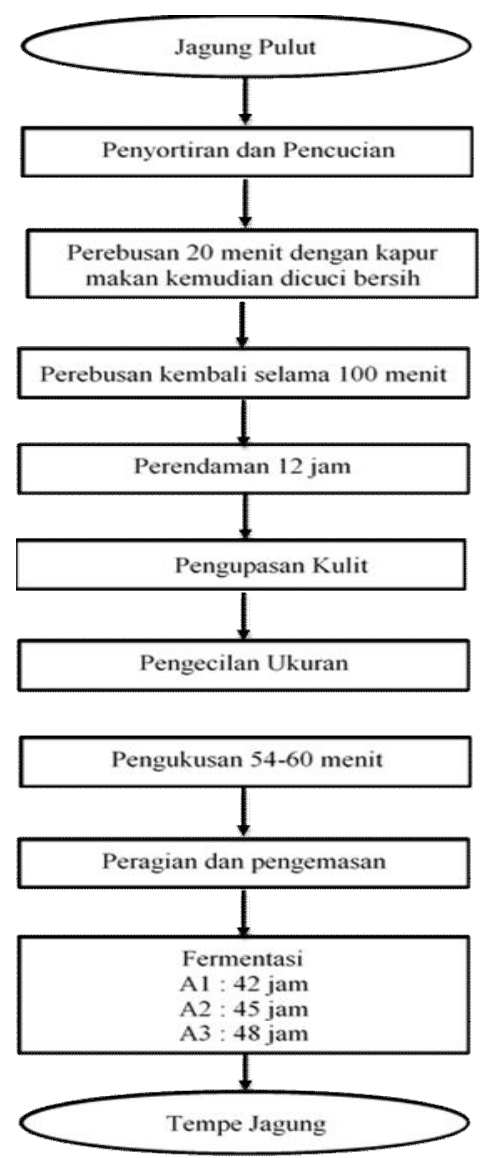

Gambar 1. Diagram prosedur pembuatan tempe jagung pulut

Sampel tempe kemudian diuji karakter kimiawinya berdasarkan metode AOAC (2005). Pengujian sampel tempe meliputi: kadar air (AOAC No. 925.10, 2005), kadar abu oven (AOAC No. 950.49, 2005), dan pH (AOAC No. 935.57, 2005). 


\section{HASIL DAN PEMBAHASAN}

\section{Kadar Air}

Kadar air suatu bahan pangan mempengaruhi penampakan, tekstur, dan cita rasa, serta berpengaruh pada umur simpannya (Winarno, 2004). Hasil analisis kadar air tempe jagung pulut (Gambar 2) menunjukkan bahwa kadar air tempe berkisar antara 65,57 - 67,61\%. Hasil kadar air tertinggi pada perlakuan A3 (67,61\%), kemudian perlakuan A2 $(66,46 \%)$, dan perlakuan A3 dengan nilai kadar air terendah $(65,97 \%)$.

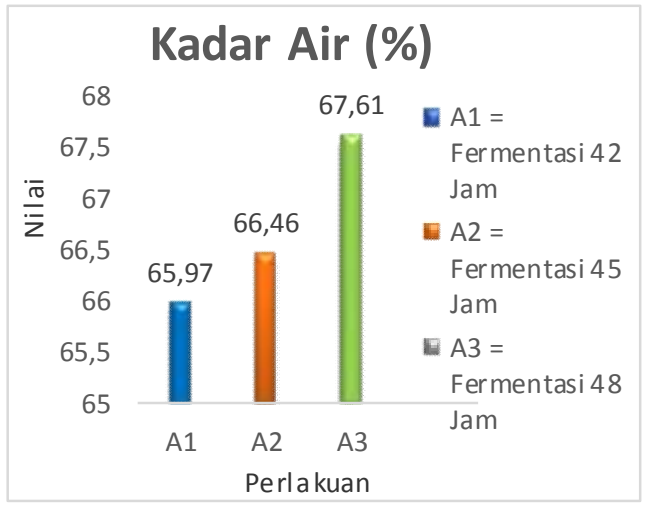

Gambar 2. Grafik kadar air

Dalam penelitian ini kadar air yang dihasilkan oleh semua perlakuan belum memenuhi standar SNI tempe kedelai (SNI 3144:2015) yang ditetapkan karena kadar air yang dihasilkan oleh semua perlakuan masih melebihi standar SNI yang ditetapkan yaitu maksimum 65\% (BSN, 2015). Hal ini dipengaruhi oleh kandungan kadar air yang terdapat dalam jagung pulut (Suarni, 2004).
Berdasarkan analisis sidik ragam kadar air diperoleh nilai $\mathrm{F}$ hitung sebesar 0,79 lebih kecil dari nilai $F(0,05)$ yaitu 5,14 dan $F$ tabel $(0,01)$ yaitu 10,92 . Hal ini menunjukan bahwa lama waktu fermentasi pada penelitian ini tidak berpengaruh nyata terhadap kadar air yang diperoleh. Hasil yang diperoleh dari pengujian kadar air tempe jagung pulut cukup tinggi sehingga tingkat kerusakan produk tempe jagung pulut cukup tinggi (Winarno, 2004).

\section{Kadar Abu}

Hasil analisis kadar abu tempe jagung pulut (Gambar 2) menunjukkan penurunan kadar abu seiring bertambahnya waktu fermentasi. Penurunan kadar abu ini diduga akibat proses fermentasi yang menyebabkan peningkatan bahan organik akibat proses degradasi oleh mikroba (Setyawati dkk., 2014).

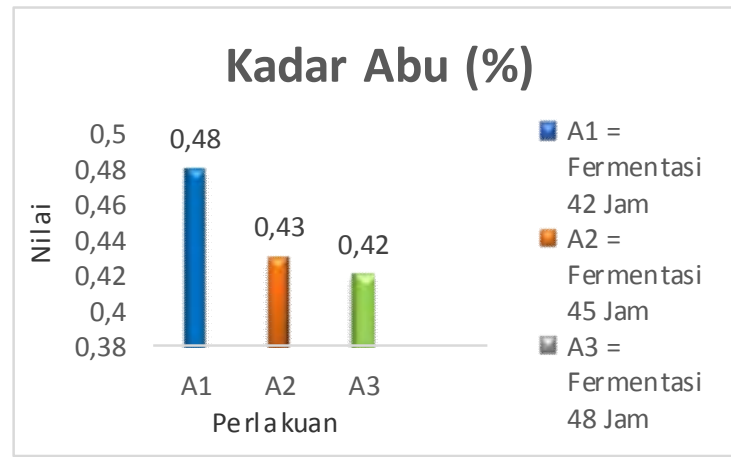

Gambar 3. Grafik kadar abu dengan nilai rata rata

Berdasarkan analisis sidik ragam kadar abu tempe jagung pulut bahwa nilai F hitung sebesar 0,78 lebih kecil dari nilai F tabel $(0,05)$ yaitu 5,14 dan F tabel $(0,01)$ 
yaitu 10,92. Hal ini menunjukan bahwa lama waktu fermentasi pada penelitian ini tidak berpengaruh nyata terhadap kadar abu.

\section{Derajat Keasaman (pH)}

Hasil pengujian $\mathrm{pH}$ terhadap tempe jagung pulut (Gambar 3) menunjukan bahwa $\mathrm{pH}$ menurun seiring bertambahnya waktu fermentasi. Hal ini diduga karena terjadinya peningkatan kandungan asam amino selama proses fermentasi (Kasmidjo, 1990).

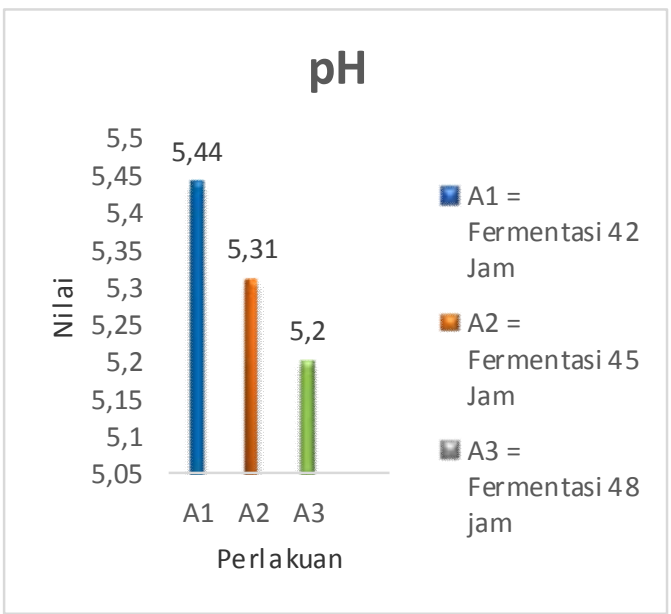

Gambar 4. Grafik derajat keasamaan $(\mathrm{pH})$

Berdasarkan analisis sidik ragam derajat $\mathrm{pH}$ bahwa nilai $\mathrm{F}$ hitung sebesar 2,17 lebih kecil dari nilai $F$ tabel $(0,05)$ yaitu 5,14. Hal ini menunjukan bahwa perbedaan lama waktu fermentasi tempe jagung pulut pada penelitian ini tidak berpengaruh nyata terhadap kadar $\mathrm{pH}$ yang diperoleh.

\section{DAFTAR PUSTAKA}

Association of Official Analytical Chemists (AOAC). 2005. Official methods of analysis of the association of official analytical chemists. Chemist Inc. New York.

Badan Pusat Statistik Provinsi Gorontalo. 2016. Produksi jagung di Provinsi Gorontalo.https://gorontalo. bps.go.id/pressrelease/2016/07/01/34 2/produksi-jagung-tahun-2015sebanyak-643-513-ton-pipilankering.html.

Badan Standarisasi Nasional. 2015. SNI 3144:2015 Tempe Kedelai. BSN. Jakarta.

Eliyana. 2017. Evaluasi sifat kimia dan sensori tempe kedelai jagung dengan berbagai konsentrasi ragi raprima dan berbagai formulasi. Universitas Lampung.

Hanifah, M. 2015. Pengaruh jenis kedelai, waktu dan suhu pemeraman terhadap kandungan protein tempe kedelai. Florea Volume 2 No. 2. SMK Kesehatan Yaleka Merauke.

Kasmidjo, R.B. $1990 . \quad$ Tempe: mikrobiologi dan kimia pengolahan serta pemanfaatannya. Yogyakarta: PAU Pangan dan Gizi. UGM.

Lestari, O.A., Mayasari, E. 2016. Pengaruh fermentasi tempe jagung terhadap kandungan protein dan karotenoid. Jurnal Teknologi Pertanian Vol. 17 No. 2.

Setyawati, N.E., Muhtarudin., dan Liman. 2014. Pengaruh lama fermentasi trametes sp terhadap kadar bahan kering, kadar abu, dan kadar serat kasar daun nenas varietas smooth cayene. Universitas Lampung, Lampung.

Suarni. 2004. Komponen nutrisi jagung pulut (waxy maize). Jurnal Stigma 2(3): 356-359.

Winarno F.G. 2004. Kimia pangan dan Gizi. PT. Gramendia Pustaka Utama. Jakarta. 